\title{
Specific hunger for potassium in the rat'
}

\section{Peter Milner and Irving Zueker ${ }^{2}$ MCGILL UNIVERSITY}

\begin{abstract}
Abstraet
The hypothesis that specific hungers are the result of rapid learning was investigated. Young rats were potassium deprived and given a single brief preference test with $\mathrm{KC1}$ as one of the solutions available. As compared with control Ss, a significantly larger proportion of deprived rats demonstrated a preference for the $\mathrm{KC1}$ during the first $5 \mathrm{~min}$., or less, of exposure to the substances. The proportion of deprived Ss making a first choice of $\mathrm{KC1}$ was also significantly greater than that of the control Ss. The results support the hypothesis that the specific hunger for potassium is not learned but is rather an innate motivational state (Morgan, 1959).

\section{Problem}

Specific hungers, produced by depriving an animal of an essential component of its diet, have been used by a number of investigators to evaluate the roles of learning and constitutional factors in the development of drives (Richter et al, 1938; Young, 1943). Hebb (1949) has suggested that learning is the important factor in self selection of diet and Bindra (1959) has criticized earlier studies (Epstein \& Stellar, 1955) as not providing a crucial test of whether or not learning takes place in the first few minutes of the initial preference test. The present study provides an analysis of the initial preference test situation in an attempt to settle the question of rapid learning in the development of specific hungers. Subjects

Twelve litters of weanling hooded rats were used $(\mathrm{N}=120)$. These animals need more potassium than adult rats and are therefore easier to deprive. There is also less chance that they have had any relevant experience with dietary deficiencies.

\section{Procedure}

Shortly after weaning each litter was divided into two groups, matched as far as possible for weight and sex. The experimental groups were fed a synthetic potassium-deficient diet. ${ }^{3}$ Control $\mathrm{Ss}$ were fed the same diet as the experimental groups with the addition of $0.75 \% \mathrm{KC} 1$. Distilled water and the diets were supplied ad lib. for about a week. By this time the deprived animals had stopped growing and a single brief preference test was given to both groups. During the test (carried out in the home cage) two drinking tubes were lowered through holes about 1.5 in apart in the middle of the top of the cage. The tubes fitted into test tubes containing the liquids used in the preference test. The ordinary water bottle and food were removed during testing.

To avoid bias in placing the rat in the cage an alley about $1 \mathrm{ft}$ long was placed against the open door and the rat placed at the end of it. It usually ran quickly into
Table 1. Preference and Initial Choice of $\mathrm{KCl}^{*}$

\begin{tabular}{|c|c|c|c|c|c|c|c|c|}
\hline \multirow[b]{2}{*}{$\begin{array}{c}\text { Litter } \\
\text { No. }\end{array}$} & \multirow[b]{2}{*}{$\begin{array}{l}\text { Test Dur- } \\
\text { ation } \\
\text { (sec.) }\end{array}$} & \multicolumn{5}{|c|}{ Control Groups } & \multicolumn{2}{|c|}{ Deprived Groups } \\
\hline & & $\begin{array}{l}\text { - Con- } \\
\text { trol So } \\
\text { lution }\end{array}$ & & $\begin{array}{c}\text { Prefer } \\
\mathrm{KCl}\end{array}$ & $\begin{array}{l}\text { First } \\
\text { Choice } \\
\mathrm{KCl}\end{array}$ & $\mathrm{N}$ & $\begin{array}{c}\text { Prefer } \\
\mathrm{KCl}\end{array}$ & $\begin{array}{r}\text { First } \\
\text { Choice } \\
\mathrm{KCl}\end{array}$ \\
\hline 1 & 300 & water & 2 & 1 & 0 & 4 & 4 & 4 \\
\hline 2 & 30 & $\mathrm{MgSO}_{4}$ & 4 & 2 & 4 & 4 & 3 & 1 \\
\hline 3 & 120 & 11 & 2 & 1 & 1 & 3 & 3 & 3 \\
\hline 4 & 60 & $"$ & 3 & 1 & 1 & 4 & 4 & 4 \\
\hline 5 & 150 & $"$ & 5 & 2 & 2 & 2 & 2 & 1 \\
\hline $6-8$ & 60 & $"$ & 13 & 6 & 7 & 11 & 9 & 8 \\
\hline \multirow[t]{2}{*}{$9-12$} & 300 & water & $\underline{14}$ & 9 & 9 & 16 & 13 & 11 \\
\hline & & Totals & 43 & 22 & 24 & 44 & 38 & 32 \\
\hline
\end{tabular}

* Some rats did not make any choice within a few minutes and are not included in the table.

the cage and after some sniffing would begin drinking. As soon as the rat licked one of the tubes a stop watch was started and the time spent drinking at each tube was recorded. At the end of the allotted drinking time, which varied from litter to litter (Table 1), S was removed and the amount drunk was recorded. The position of the tubes was reversed for successive rats.

All litters were given a choice between $0.1 \mathrm{~N} \mathrm{KCl}$ and a control solution (Table 1 ). The $\mathrm{MgSO}_{4}$ solution (which rats neither avoided nor preferred) was used to make sure that the deprived Ss were not merely attracted to anything that tasted different from their usual regimen.

Only two out of five Ss in the control group of litter one drank from either of the tubes within a reasonable time, although all experimental Ss did so immediately. While this is interesting in itself, it was thought important to uncover any latent preferences or aversions in control Ss, so in subsequent litters control Ss were water deprived for 12-20 hr. before the preference test.

\section{Results}

In preliminary studies it was found that there was a 0.97 correlation between the amount of fluid consumed and the time spent drinking so only the latter measure was used in the analysis of the data.

In order to obtain comparable measures of preference for the different litters which were not all allowed the same length of time to drink, a simple dichotomous score was adopted. If $\mathrm{S}$ drank for a longer time from the $\mathrm{KCl}$ tube it was said to prefer $\mathrm{KCl}$. The first choice of each $\mathrm{S}$ was also recorded (Table 1). The times the different litters were given to establish preferences after they had begun to lick one of the tubes are also shown in Table 1.

The difference between the number of control and experimental Ss preferring $\mathrm{K}$ was highly significant $\left(x^{2}=125 ; \mathrm{df}=1 ; \mathrm{p}<.001\right)$. Deprived Ss also initially chose the KC1 solution more frequently than control 
Ss $(p<.05$, one-tailed test). The use of a one-tailed test is justified since it is hardly likely that the deprived rats would avoid potassium salts.

For the last four litters tested, the amount of time spent drinking from the $\mathrm{KC} 1$ tube during each of the $10,30-$ sec. intervals was analysed. It was found that the amount of time spent drinking declined from the earlier to the later $30-\mathrm{sec}$. intervals of the period, i.e., maximum preference for $\mathrm{KCl}$ was observed in the initial 30-sec. interval.

\section{Diseussion}

The results indicate that rats have a specific hunger for potassium. Furthermore they suggest that this hunger is innate rather than dependent on learning. Olfactory cues probably are important in the correction of the experimentally induced potassium deficiency, since potassium deprived animals chose the $\mathrm{KCl}$ solution before they drank from either solution.
Referenees

BINDRA, D. Motivation: A systematic reinterpretation. New York: Ronald, 1959.

EPSTEIN, A. N., \& STELLAR, E. The control of salt preference in the adrenalectomized rat. J. comp. physiol. Psychol., 1955, 48, $167-172$.

HEBB, D. O. The organization of behavior. New York: Wiley, 1949. MORGAN, C. T. Physiological theory of drive. In S. Koch (Ed.), Psychology, a study of a science. Vol. 1. New York: McGrawHill, 1959. Pp. 644-699.

RICHTER, C. P., HOLT, L. E., \& BARELARE, B. Nutritional requirements for normal growth and reproduction in rats studied by the self selection method. Amer. J. Physiol., 1938, 122, 734-744.

\section{Notes}

1. Supported in part by NRC(Canada) grant APA 66 and Grant M-2455 of the United States Public Health Service.

2. Now at Department of Reproductive Physiology, Oregon Regional Primate Research Center, Beaverton, Oregon.

3. The assistance of Dr. Hendrikson in supplying suitable formulae for the diets is gratefully acknowledged. The vitamins were kindly donated by E. R. Squibb \& Sons. 